\title{
Muhammad Iqbal - Reconstructing Islam along Occidental Lines of Thought
}

\author{
Stephan Popp \\ Institute of Iranian Studies, Austrian Academy of Sciences, \\ Hollandstrasse 11-13, 1020 Vienna, Austria \\ stephan.popp@oeaw.ac.at; stephan.popp@gmx.net
}

\begin{abstract}
The philosopher Muhammad Iqbal is officially seen as the inventor of the idea of Pakistan and is considered to be the national poet of the country. Indeed, he is one of the most important Islamic modernists, a source of inspiration for enlightened Islam today, and one of the great philosophers of life in the first half of the 2oth century. This article explains the main concepts of philosophy: "self", "love", "intuition", his philosophy of time, his concept of Islam, and his critique of the West. It then traces the influences on his thought from Islamic thinkers, from the Western philosophers Fichte, Kant, Nietzsche, and Bergson, and the Influence of the Indian society he was living in. Iqbal claimed that all his ideas derived from his thorough reading of the Quran. However, the questions that shaped his answers were very much in the form of the European philosophy of the time, and in that of the discourses of his society too.
\end{abstract}

\section{Keywords}

Philosophy (1900-1940) - Pakistan - modern Islam - Allama Muhammad Iqbal

\section{Introduction}

Muhammad Iqbal from Lahore, then British India, is not very well known in German-speaking countries. Yet, he can be regarded as one of the great representatives of the philosophy of life ("Lebensphilosophie") beside Nietzsche and Bergson, both of whom he had studied. He is one of the few theorists of Islam who have understood and replied to Kant. With his call for individuality 
as the aim of the Quranic revelation, he has recently been taken up as a model for Islam in the 21st century by progressive Muslims.

From his preoccupation with the Quran, Iqbal found answers to the questions posed by societal change, colonialism and British education that are Quranic on the one hand, but are filtered by the discourses in British Indian society around 1900, and by his readings of Goethe, Nietzsche, Kant, and other Western philosophers. New approaches to interpreting the Islamic tradition were in the air at that time, not because of current fashion, but due to the urgent question of how to deal with the colonial power.

In her extensive study on Iqbal, Gabriel's Wing, Annemarie Schimmel has derived as much as possible of Iqbal's thought from the Islamic tradition. She is, however, very much aware that Iqbal has written things that are very bold and at times shocking to an orthodox Sunni Muslim. Therefore, I suppose that although Iqbal's philosophy is firmly rooted in the Quran and Islamic learning, it cannot be explained from these sources only, although Iqbal insisted on that. He often is a veritable anti-traditionalist, and some of his ideas are novel to Islamic thought but quite common in the West. We will enlarge on this later.

\section{Indian Islam around 1900}

Muhammad Iqbal was in no way alone with his concern. Since the great freedom struggle of 1857 had been put down and the British crown colony of India established, the great question of the Indian Muslims was how to deal with that colonial power. The British saw themselves as superior and had prevented the Industrial Revolution in India (though there were some efforts), so that Indian raw material went to Great Britain for processing, in order to be sold as finished products for the profit of England. ${ }^{1}$ They claimed to lead India out of the 'dark age of Islamic rule. They did leave the traditional Sharia law to the Muslims, but they implemented it in a British way, so that the Muslims of India found themselves in an entirely different law system with some Islamic content. ${ }^{2}$ The British did not hesitate to tear down mosques for building projects or confiscate Islamic charitable trusts that financed schools or hospitals. ${ }^{3}$ They replaced the Islamic education of the Mughal Empire with the British school system. Later, the formally independent princely states

1 Parthasarathi 2011, pp. 251-258.

2 Metcalf 2007, p. 49.

3 Sikand 2005, p. 62. 
demanded a British education of their government officials, too, because they were convinced that the requirements of the modern age could only be taught in English. ${ }^{4}$ Therefore, Islamic schools had to rely on the poorer classes that were not admitted into a state career anyway. This is true even today. Islam was pushed into the private sphere, a concept that did not even exist before. ${ }^{5}$

The Muslims of India reacted on that 'threat to Islamic society' very diversely. Some retreated into orthodox Islamic milieus in order to build a renewed Islamic society from there. It is an old Islamic belief that God will send a 'renovator' (mujaddid) of Islam every 100 years. ${ }^{6}$ Thus, some Mullahs founded the school of Deoband in 1866, which represents a strictly orthodox Hanafi Islam and issues Islamic legal opinions ( fatwa) for all circumstances. It was modelled on British mission schools, not on traditional Islamic schools (madrasa). Today, it is the most important educational institution in the entire Islamic world after the Al-Azhar University in Cairo. ${ }^{7}$ This madrasa is rather sceptical to the beliefs and practices of the majority, which is informed by Sufism, such as the belief in intercession, music in worship, grand festivals and sacrifices for saints. In 1905, the scholar Ahmad Riza Barelvi therefore founded schools that stress Sufism. ${ }^{8}$ Both schools meanwhile have offshoots in India, Pakistan and Bangladesh, in Eastern Africa and in Great Britain, and antagonize each other intensively. Both preach separation from an evil world and try to set up a pure, Islamic milieu. ${ }^{9}$ Islamism, which is based on this effort and tries to transform the entire society into an Islamic milieu, is beyond the time frame that we consider here. One of its most important theorists, Abu l-A'la Maudoodi and his Jamaat-i Islami (founded in 1941), came from India, too. ${ }^{10}$ His influence on politics in Pakistan led to the prevention of Pakistan becoming the secular state that its founder Jinnah wanted it to be.

On the other hand, there were Muslims who did not object to British rule and tried to integrate more Muslims into the British state. Especially worth mentioning is Sir Sayyid Ahmad Khan, who founded the Muhammedan Anglo-Oriental College in 1875 (since 1920 Aligarh Muslim University). This college provided Muslims with a modern British university education based on Islamic culture. However, because the rationalist Sir Sayyid was open to modern science and interpreted the Quran in that sense, strict Deobandi mullahs

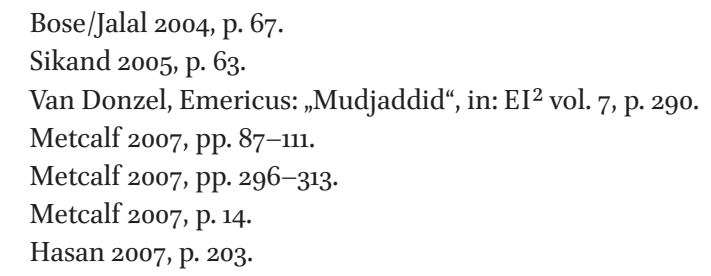


declared him an infidel and accused him of being a 'nature-worshipper' (in Urdu: necharī)..11

\section{Iqbal's Life in Brief}

Into this climate of debate about correct Islam and its interactions with the non-Islamic lords of India, Muhammad Iqbal was born in Sialkot, Punjab, probably in 1877 . His grandfather had been a Kashmiri Brahmin who converted to Islam. Thus, he belonged to a respectable but not noble family in the very hierarchical society of Indian Islam. Iqbal's father ran a tailor's shop ${ }^{12}$ and was a very pious follower of the Qadiri Sufi order. Accordingly, he fostered the interest for the Qadiris' very Neo-Platonic interpretation of Islam, for its theorist Ibn Arabi, and for classical Persian poetry, especially for Hafiz, who was considered a poet of this kind of mysticism in India, in his son very early on. Iqbal's schoolteacher in Sialkot, however, Syed Mir Hasan, was a fervent adherent of Sir Sayyid Ahmad Khan's Aligarh movement, and awakened Iqbal's interest for the modern sciences. In 1895, 18-year-old Iqbal went to Lahore, studied English, Arabic and philosophy, and became lecturer of Arabic at the University of the Punjab in 1900. His first Urdu poems in the style of the English Romantics are from that time. Moreover, he wrote the first children's poems in Urdu. In 1905, he went to Cambridge, ${ }^{13}$ and in 1907 to Heidelberg, where he studied Kant and Hegel, learned German, fell in love with his German teacher Emma Wegenast, and read Goethe's Faust and Nietzsche. ${ }^{14}$ In 1908, he returned to Lahore with a $\mathrm{PhD}$ and became a barrister. However, reintegrating into Lahore society precipitated a deep crisis, during which he divorced his wife, married again and developed his philosophy. The first fruit of this philosophy was the rhymed essay Asrar-i Khudi (The Secrets of the Self) in 1915. Because many people understood the title as The Secrets of Egotism, a scandal arose that made Iqbal famous. In the next ten years, he wrote poems in the spirit of his philosophy ${ }^{15}$ and went into politics in 1927, but with moderate success. ${ }^{16}$ In 1928 and 1929, he held a series of lectures on his philosophy that became his main philosophical work

\footnotetext{
Metcalf 2007, pp. 317-335.

Singh 1997, p. 2.

Schimmel, 1963, pp. 35-37.

Singh 1997, pp. 156-158.

Singh 1997, pp. 44 et seq.

Schimmel 1963, p. 48.
} 
as The Reconstruction of Religious Thought in Islam. ${ }^{17}$ On New Year's Eve 1930, he held the opening speech of the Muslim League congress, which Pakistan sees as the hour of its birth. In it, he demanded a reorganisation of the Muslimmajority parts of western India into one single province, so that the Muslim majority would be represented as such. In $193^{1}$ and 1932, he took part in the round table conferences on the future of India, and met the philosopher Henri Bergson in Paris. ${ }^{18}$ His third philosophical work, the Javidnama (meaning both The book of Eternity and The book for (my son) Javid) appeared in 1932, too. In this philosophical epic, the poet undertakes a journey through the heavens and discusses philosophy and politics with deceased celebrities. More poems followed. ${ }^{19}$ From 1935 on, his health began to worsen, probably because of laryngeal cancer. ${ }^{20}$ On 20 April 1938, Iqbal passed away. ${ }^{21}$

In India and Pakistan, Iqbal is above all famous for his poetry. It is deemed to be difficult, but it has enriched Urdu poetry with its themes and with imagery suitable to the very rigid standards of the poetry before him. In doing so, Iqbal went beyond the scope of the old motifs and paved the way for modern Urdu poetry.

\section{$4 \quad$ Iqbal's Philosophy}

Let us continue to an outline of Iqbal's philosophy now. The philosophers that Iqbal has studied are above all Kant, Hegel, and Nietzsche. Additionally, his reading of Goethe's Faust had a great impact on him, and Fichte's philosophy of subjectivity is more visible in his thought than Hegel. In later years, Iqbal is influenced by Henri Bergson. However, Iqbal himself was convinced that he wrote about nothing but "Islam". To explain this, he wrote to Maharaja Kishen Pershad, the prime minister of Hyderabad:

I am astonished that you also imagine that I have written German philosophy in this epic. The scholars of Islam have been opposed to essentialist (or, pantheistic, vujūdīya) Sufism from the beginning until today.

\footnotetext{
17 Schimmel 1963, p. 49 et seq.

18 Schimmel 1963 , pp. 51 et seq.

19 Schimmel 1989, p. 39.

$20 \quad$ Singh 1997, p. 131.

$21 \quad$ Singh 1997, p. 132.
} 
I have not said anything new. Among the Hindus, Krishna's Gita (as far as I understand) is an excellent voice against it. ${ }^{22}$

However, Iqbal changed traditional Islam quite a bit for this purpose, claiming that his philosophy was the rediscovery of original Islam.

\subsection{Khudi}

Iqbal's central concept 'khudi' has been mystified very much and construed as 'essence of the soul' etc. However, Iqbal himself gives an English translation for it in the same letter: Individuality:

[...] Anyway, wherever I have used this word, it is intended to mean "essential personality" (tashakhkhuṣ-i $i \underline{z} \bar{t} \bar{\imath}$ ) or "the feeling of the ego" (iḥsās- $i$ nafs). This is the translation of the English word Individuality. As far as I know, there is no such word in our language to express this concept, which one could use in poetry. ${ }^{23}$

Khudi is usually translated as self, relating it to the Hindu concept of ätman that Iqbal himself alludes to by mentioning the Bhagavadgita (above). Iqbal's main point is that the individual is a value in itself, and that it is not destined to dissolve in God in the end. What is more: the world consists of nothing but egos. Every atom has its ego. Matter consists of egos only:

I have conceived the Ultimate Reality as an Ego; and I must add now that from the Ultimate Ego only egos proceed. The creative energy of the Ultimate Ego, in whom deed and thought are identical, functions in egounities [...] Every atom of Divine energy, however low in the scale of existence, is an ego. ${ }^{24}$

Aggregations of egos again have an ego, which is collective and more complex than the egos of its parts. Every liver cell has its ego, the liver has its ego, the body has its ego, the human person has its ego, the family has its ego, the village has its ego, the nation has its ego, humankind has its ego, earth has its ego,

22 Letter to Maharaja Kishen Pershad, Prime Minister of Hyderabad, of 24th June 1916, in: Barnī 1991, vol. 1, pp. 505 et seq. Translation from Urdu by the author of this article.

23 Letter to Maharaja Kishen Pershad, Prime Minister of Hyderabad, of 24th June 1916, in: Barnī 1991, vol. 1, pp. 505 et seq. The two Urdu terms are problematic nevertheless, because nafs does mean the egoistic ego, too, and tashakhkhuṣ-i zzātī can mean "identification by caste". Iqbal tries to avoid misunderstanding by using them as synonyms. Iqbal 1934, p. 68. 
the galaxy has its ego, the world has its ego, and God has his absolute ego that encompasses all egos. The ego is "not a thing but an act", as Iqbal says referring to the Quran: "The Spirit (ar-rüh) is by command (amr) of my Lord" (Surah 17.85). ${ }^{25}$ Thus what Iqbal means is not our psyche but its foundation: intending to be (seen from our point of view), and being intended (seen from God's point of view). The soul therefore does not consist of a substance that exists out of itself because it is based on mere intention.

Citing Henri Bergson's L'évolution créatrice, Iqbal accepts Darwin's theory of evolution as a part of the evolution of the egos that the world is built of. ${ }^{26}$ The meaning of life is to develop this free individuality further. Individuality is the much-discussed "trust" (al-amāna) of the Quran (33.72), which heaven, earth and mountains refused but humankind accepted. ${ }^{27}$ To illustrate this, Iqbal wrote the poem Conquest of Nature. It describes Adam's expulsion from paradise as Adam emerging out of passivity into a world of responsibility, where failure, but also full development, is possible. ${ }^{28}$ This development makes humankind God's vice-regent on earth (Quran 2.30), ${ }^{29}$ and God's co-worker too. ${ }^{30}$ Iqbal admits that such concepts are in stark contrast with traditional Sunni Islamic theology, especially the doctrine of predestination. However, he calls this a misinterpretation of the Quran caused by medieval politicians who wanted to justify their actions. ${ }^{31}$ According to Iqbal, the development of the ego will never reach a goal:

Nor is heaven a holiday. Life is one and continuous. Man marches onward to receive ever fresh illuminations from an Infinite Reality which 'every moment appears in a new glory'. And the recipient of divine illumination is not merely a passive recipient. ${ }^{32}$

In this concept, "infinite reality" (God) is the highest ego, whose parts, the "recipients", are the smaller egos. The concept is directed against fatalism and passivity above all, which result from a pantheist mysticism that regards the ego as an illusion. Instead of dissolving in God in the end, human

\footnotetext{
25 Iqbal 1934, p. 97. Quran translation by Pickthall.

26 Iqbal 1934, p. 59.

27 Iqbal 1934, p. 83.

28 Iqbal, Payām-i Mashriq, in: Iqbal 1990, pp. 255-258. Translations from Persian and Urdu, if not mentioned otherwise, are by the author of this article.

29 Iqbal 1934, p. 90.

$30 \quad$ Iqbal 1934, p. 69.

31 Iqbal 1934, pp. 104 et seq.

32 Iqbal 1934, p. 117.
} 
beings should discover divine power within themselves, as Iqbal writes: "The weak lose themselves in God; the strong discover Him in themselves." ${ }^{33}$ Iqbal claims that "Heaven and Hell are states [of mind], not localities." ${ }^{34}$ This is a very common thought in Christianity, ${ }^{35}$ but at least very progressive for an Islamic thinker, for the majority of Muslims believes that Heaven and Hell will be actual places.

Iqbal calls an individual who has fully realized the potential of his self the "Believing Man" (mard-i mu'min), or "Man of God" (mard-i haqq) ${ }^{36}$ in which "man/male" bears the connotation of an "accomplished mystic". Iqbal's concept derives from the Sufi ideal of the "Perfect Man" (insān-i kāmil), who embodies all the attributes of God (but not the essence), and whose perfect example traditionally is the Prophet. Iqbal has treated this concept in 1900 in an article already before he went to Europe, but the novelty with him is the emphasis he lays on his "Man of God" being God's counterpart. To Iqbal, assimilating Divine attributes does not mean merging with God but merging God into oneself. ${ }^{37}$ Such a person is able to shape the world according to his will because the fully developed potential of that person's self is God's own will. ${ }^{38}$ In chapter 10 of the Secrets of the Self, he presents Ali b. Abī Talib, the prophet's old friend and son-in-law, to whom all Sufi traditions trace their origin, as a role-model for such a person.

In the Secrets of the Self, Iqbal's polemic is mainly directed against a fatalism that disapproves of engaging in the world and waits for dissolving in God. In his poetry, Iqbal opposes the traditional Persian and Urdu image of the moth that dies in the flame of love with his new image of the firefly, which has light burning within himself. ${ }^{39}$ As a self-conscious ego, man approaches God as a

33 Iqbal: Stray thoughts, No. 1, in: Iqbal 2006.

34 Iqbal 1934, p. 116.

35 Cf. Catholic catechism part 1, section 2, chapter 3, Art. 12.II (paragraph 1024): "Heaven is ... the state of supreme, definitive happiness." Westminster Shorter (Anglican) Catechism, question 38: "the full enjoyment of God for all eternity." Heidelberg (Reformed) Catechism, question 58 : "a blessedness in which to praise God forever".

$36 \quad$ Iqbal 1990, pp. 664 et seq.

37 Schimmel 1963, pp. 118-122.

38 Schimmel 1963, pp. 111 et seq.

39 E.g. in the poem "Kirmak-i shab-tāb” ("The Firefly"): "O firefly, all of you is light / Your flight is a chain of (Divine) hiddenness and presence / it is the manner of epiphany." ( $A i$ kirmaki-i shab-tāb, sarāpā-yi tu nūr ast / Parvāz-i tu yak silsila-yi ghaib-u huzūūr ast / Āȳñ-i $\dot{z} u h u \bar{r}$ ast.) Stanza 6, in: Iqbal: Payām-i Mashriq, in: Iqbal 1990, p. 276. 
friend. Half in jest, Iqbal can even say: "Take a little rest at my bosom / From the heavy work of being God!"40

\section{2 "Love"}

So the world consists of egos only, which combine to ever bigger egos until the ego of everything remains. In order to understand Iqbal, we have to banish the thought that matter and spirit are different things. Everything is an ego. We are not alive because there is a soul in our matter, but our matter is part of our soul. We are a soul that consists of souls, which consist of souls ... So because all those egos keep developing, an impulse is necessary that spurs this development. Iqbal calls this impulse love in the Secrets and in his poems, in Persian 'ishq or nazar ("glance"). ${ }^{41}$ Thus, love is not the encounter with someone else for him, but an impulse of growth, a desire for the acquirement of new qualities. ${ }^{42}$ In this sense, eating is an act of love, and reading this article is an act of love too. To Iqbal, love is that which holds the world together. He does not speak about love between two people, because traditional Islamic mysticism is based already upon the Neo-Platonic concept of Eros. ${ }^{43}$ Iqbal takes the concept from mysticism, but adapts it to his goal to develop the self further. Love has an active and a passive side: acquirement itself is passive, but people need to act in order to reach it. Everything human beings do are attempts at developing further according this urge for acquirement.

\subsection{Intuition}

Iqbal develops his epistemology based on this theory of "love", following Bergson to a great deal in his Reconstruction. There are two kinds of cognition: rational, and intuitive. Both are valid in their own way. Rational cognition is systematic, reproducible in all parts, informed by language and therefore teachable by language, and suitable for the physical world above all. Intuitive cognition is also called "heart" by Iqbal, who refers to the Quran and Islamic mysticism here. We use this kind of cognition when we get to know somebody. It also includes the findings we have in prayer or meditation. It occurs at once, not step by step. It cannot be separated from the object of our experience. It is only partially accessible to language, but verifiable by analogy. As a sudden

40 "Dar sina-yi man damē biyāsāy / az mihnat-i kuluft-i khudāü" in: Iqbal: Zabūr-i Ajam (Persian Psalms), Part I, No. 30, verse two. In: Iqbal 1990, p. 427.

41 Iqbal: Asrār-i Khudī (The Secrets of the Self), chapter 3: "Showing that the Self is strengthened by Love", translation by Reynold Nicholson (see Appendix, translations), Original in: Iqbal 1990, pp. 18-22.

42 Schimmel 1963, p. 128.

43 Schimmel 1963, pp. 129 et seq. 
kind of knowledge, it is not governed by serial time. Because knowledge about the essence of man or of God is hard to obtain in a rational way, this kind of knowledge is above all useful for metaphysics. Hence, both kinds of knowledge are useful in their own way. ${ }^{44}$ If knowledge is to be verifiable for many, rational knowledge is better, and if it is to increase quickly, intuitive knowledge is better. However, because rightful action is based on metaphysics, intuition is ultimately superior. ${ }^{45}$ At least, rational knowledge would take too much time.

\subsection{Time}

As we noted, there are only egos for Iqbal, which grow by cognition. Space and time are being created by the egos in order to aid cognition. Here, Iqbal refers to Kant. ${ }^{46}$ More exactly, every ego creates its own time in order to interact with other egos. ${ }^{47}$ Time is not necessary for knowing oneself. Those who have meditated before will have noticed how the perception of time changes in meditation. Iqbal was a member of the Qadiri Sufi order and did meditate, as his remarks on mystical experience as a means of knowledge show. In the Javidnama, he cites the Prophet's dictum "I have a time with God to which not even Gabriel has access" in order to start his imaginary journey to the heavens and discuss with departed philosophers and politicians. ${ }^{48}$

Because God is an ego, too, time stands still for God: "But real time is not serial time to which the distinction of past, present, and future is essential; it is pure duration, i.e. change without succession." ${ }^{49}$

What is called "destiny" is nothing but seeing things under the conditions of the standing time of the soul. God has not determined anything "before the creation of the world" because there was no 'before' before the creation of the world. This is not only true for the divine ego but also for any ego, unless it subjects itself to regarding the world in a causal, rational way. Time stands still for the soul as well. ${ }^{50}$ It can connect with God and change its destiny by simply seeing things in a different way. In any case, destiny is not a pretext for inaction.

44 Iqbal 1934, pp. 15-22.

45 In poetry, Iqbal once expressed it thus: "Reason is love, too, and not alien to the delight of glances, / But that wretch does not have that daring courage.” („Aql ham 'ishq ast-u az żauq-i nigah bēgāna nēst / Lēkin ìn bēchāra rā ān jur'at-i rindāna nēst.") Iqbal: Zabūr-i Ajam (Persian Psalms), part I, no. 20, verse 1, in Iqbal 1990, p. 418.

46 Iqbal 1934, p. 37.

47 Iqbal 1934, p. 71.

48 Iqbal:Javìdnāma, in Iqbal 1990.

49 Iqbal 1934, p. 55.

5o Iqbal 1934, p. 72 . 


\subsection{The East}

With this view of intuition (or "love") as an equally valid or even superior means of cognition, Iqbal is in line with all those critics of colonialism who claim that 'the East' has always cultivated intuitive knowledge more than rational knowledge, but it is not 'backward' because of that, as the colonial officials often claimed. This is because the occident, in return, is backward in intuitive knowledge according to Iqbal (and Gandhi, and Tagore, and the other theorists of Indian independence in general). Both have to learn from each other, as Iqbal writes in his political-philosophical epic Javidnama, "The East saw God but did not see the world, / The West crawled about in the world and fled from God." ${ }^{11}$ Feelings of superiority still creep in because ethics needs intuition.

\subsection{Islam}

Iqbal was convinced to preach nothing but original, 'Arabic' Islam, which he had freed from the deadweight of the centuries, especially from the deadweight of Neo-Platonic, quietist pantheistic philosophy. Iqbal believes in an adaptable Islam, which adapted to the late antique world in the very beginning, and needs to remain adaptable. ${ }^{2}$ He rejects the teaching of orthodox Sunni Islam that imitating the great jurists is enough to solve all problems and writes in an early verse, "Suicide is better than the method of imitation." ${ }^{33}$ In this respect, he is a prominent Islamic modernist like Sir Sayyid Ahmad, who tries to renew Islamic society not so much from Islamic jurisprudence but from the adaptation of the ethical principles of Islam on modern society.

On his journey to Germany and is his crisis after that, Iqbal changed from an Indian nationalist to a pan-Islamist. This may have been triggered by the political events of those years, especially the conquest of Libya by Italy in 1912, and then the demolition of the Ottoman Empire and the occupation of Iran by Great Britain and Russia after World War I. For many Islamic intellectuals, this looked like a destruction of the political influence of Islam as a whole. In this context, pan-Islamism was attractive to many of them, with its demands of the reestablishment of one state for all Muslims, of reforming Islam to the way it was in the times of the first three generations (Salafism), and of having spiritual reasons for using modern technology. ${ }^{54}$ Thus, Iqbal still resembles

\footnotetext{
51 "Sharq haqq rā dìd va 'ālam rā nadīd, / Gharb dar 'ālam khazìd, az haqq ramīd." Iqbal: Javìdnàma, in: Iqbal 1990, p. 624.

52 Iqbal 1934, p. 170.

53 "Taqlīd kē ravish sē tō behtar hai khudkushī." Iqbal: Bāng-i Darā (The Call of the Marching Bell), part I (poems before 1905), ghazal 13, verse 3a, in: Iqbal 1998, p. 133.

54 Singh 1997, pp. 38 et seq.
} 
the Neo-Romantic Indian nationalists. He only replaced the nation with the umma, the community of Muslims.

According to Iqbal, Muhammad was the last prophet because be replaced prophecy with human rationality. Iqbal believes that the Quran refers to this in Surah 41:53: "We shall show them Our signs in the horizons and in themselves, till it is clear to them that it is the truth." That is, Iqbal says, in science, historiography and psychology, from which follows that man is called to take his destiny in his own hand as God's vice-regent, and to subdue to nobody who claims sacred authority, be it kings or priests. According to Iqbal, Islam invented applied science and therefore technology (because old Greek science aimed at theory), moreover it introduced internationalism (because all Muslims form one umma), and fused politics and religion. ${ }^{55}$ Christianity was too detached from the world for him. According to Iqbal, Christianity tries to live its ideals at the cost of the real situation, whereas Islam searches to unite reality and ideals in a continuous process. ${ }^{56}$

In law matters, Iqbal is only rarely precise. In the beginning, he is rather an aristocrat: "Flee the ways of the republic, serve mature action, / For a human thought does not come from two hundred donkey brains!', as he writes in a poem. ${ }^{57}$ However, he later arrives at parliamentarism, probably via his political work. He demands "to open the gate of ijtihad" as the slogan goes, that is, to allow independent finding of justice by Islamic jurists once again, which had been declared superfluous by Sunni orthodoxy. For this aim, he interprets the classical legal remedy of conclusion by analogy ( $q i y \bar{a} s)$ as "only another name for Ijtihād which, within the limits of the revealed texts, is absolutely free"s8 He does not want to entrust this finding of justice with individual people but with a parliament. According to him, this corresponds with the other classical legal remedy besides the Quran and the sayings of the Prophet, the "consensus of the scholars" $(i j m \bar{a})$. Iqbal claims that by using it in a parliament, scholarly consensus would come into its own for the first time in Islamic history. ${ }^{59} \mathrm{He}$ does not say anything more precise about it.

55 Iqbal 1934, pp. 120-122.

56 "The great point in Christianity is the search for an independent content for spiritual life which, according to the insight of its founder, could be elevated, not by the forces of a world external to the soul of man, but by the revelation of a new world within his soul. Islam fully agrees with this insight and supplements it by the further insight that the illumination of the new world thus revealed is not something foreign to the world of matter but permeates it through and through." Iqbal 1934, p. 8. "Republic" (Jumhürīyat), in: The Message of the East (Payām-i mashriq), chapter "Thoughts", p. 133, in: Iqbal 1990, p. 302.

$5^{8} \quad$ Iqbal 1934, p. 169.

59 Iqbal 1934, p. 165. 
Iqbal knew very well that actually existing Islam in the Punjab was very different from that, and he showered it with complaints and sometimes even mockery, as in the poem about the mullah in heaven. There, he claims that mullahs are wrong in heaven because they do not like heavenly wine and beauties, and they will not find there what they delight in, i.e. rote-learning, debates, quarrels and narrow-minded communities. ${ }^{60}$ Iqbal calls upon his fellow believers not to consider the Muslims representatives of true Islam: "Come out of the Muslims, flee into being a Muslim! / The Muslims honour the heathen who adores past things." 61

Influences

In the second part, I would like to suggest some answers to the questions where Iqbal took his ideas. Iqbal himself repeatedly answered this question with: From the Quran. He was convinced to do nothing but explain the message of the Quran for the 1920s and 1930s. However, Iqbal's understanding of the Quran often is very inventive. For example, he interprets surah 23:14: "God is the best creator" to the effect that human beings are creators too - not as good as God but creators nevertheless. This is very shocking for an orthodox Muslim. ${ }^{62}$ Thus, we must ask ourselves what has formed his mind in a way that he understood Islam like this.

\subsection{Islam}

First, we have Iqbal's very pious lower-middle class parents. Iqbal grew up in the pantheistic beliefs of his father, in which Ibn Arabi and the piously interpreted poet Hafez ranked right after the Quran. According to Ibn Arabi, the world is the self-unfolding of God and works like a human being, so that every human being contains all of God in a small form. ${ }^{63}$ So what is new with Iqbal is only that he deems humans to be imperishable. Secondly, Iqbal wrote his doctoral thesis about the Neo-platonic mystics of Iran, especially Suhravardi, whose system of "desire" (zauq) for enlightenment by the next higher light

\footnotetext{
60 "Mullā aur bihisht“ (The mullah and Paradise), in: Iqbal: Bäl-ijibrïl (Gabriel's Wings) no. 117, in Iqbal 1998, p. 445.

61 Burūn à az musalmānān, gurēz andar Musalmānn̄!! / Musalmānān ravā dārand kāfir-i mäjarāīhä. "Iqbal: Persian Psalms, 7th ed. 1961, part II, poem 56, last verse.

62 Schimmel 1963, pp. 116 et seq.

63 Ibn 'Arabī 2005, p. 37.
} 
has influenced Iqbal's idea of love thoroughly. ${ }^{64}$ Thirdly, as an adherent of the Qadiri order, Iqbal was familiar with the prophet being regarded as "light and human" (nür wa-bashar), ${ }^{65}$ the acceptance or rejection of which has split South Asian Islam into three confessions. ${ }^{66}$ Just as for the Sufis, the way of loving God leads via Muhammad with Iqbal, as he writes in the Secrets in the chapter about strengthening the self by love. ${ }^{67}$ If Iqbal calls us to perfect ourselves continuously, he calls us to model ourselves on the Prophet, and not only morally but also ontologically. 68

Iqbal does not discuss the problems of traditional Islam in depth. Rather, he dismisses it as backward or as a dualist Greek influence that is contrary to the spirit of the Quran. An example for the latter case is his treatment of the classical Islamic theological concept of the soul as "a finer kind of matter or a mere accident which dies with the body and is re-created on the Day of Judgement." ${ }^{69}$ Iqbal declares this a Greek influence created by the conversion of Christian and Persian intellectuals to Islam, who brought their dualist concept of body vs. soul with them. Both Islamic mystical experience and the statements of the Quran, however, do not follow this concept, Iqbal states. Then he refers to Muslims whom he thinks being critical of it, after which he discusses Francis H. Bradley and explains al-Ghazāli's concept of the soul with Kant. Even in describing mystical experience in this place, Iqbal relies on Louis Massignon's interpretation of the mystic al-Hallāj. ${ }^{70}$ As an example for backwardness, Iqbal justifies Islamic finding of justice (ijtihād) with stating that the spirit of Islam was dynamic from the very beginning, and that finding of justice was forbidden in Sunni Islam because "conservative thinkers" were afraid of rationalist thought "and considered it a danger to the stability of Islam as a social polity."71 Therefore, intellectuals were discouraged to participate in politics, according to Iqbal, and pushed into speculative philosophy. ${ }^{72} \mathrm{~A}$ third strategy of Iqbal is relying on authorities that are famous but marginal in the conservative Islamic discourse. For example, he bases his idea that atoms are

\footnotetext{
64 Schimmel 1963, p. 38.

65 Schimmel 1963, pp. $156-158$.

66 Sikand 2005, pp. 59 et seq.

67 Iqbal: Asrär-i Khudī (The Secrets of the Self), chapter 3: "Showing that the Self is strengthened by Love", translation by Reynold Nicholson (see Appendix, translations), Original in Iqbal 1990, pp. 18-22.

68 Schimmel 1963, p. 159 .

69 Iqbal 1934, p. 91.

$70 \quad$ Iqbal 1934, p. 91.

71 Iqbal 1934, p. 142.

72 Iqbal 1934, p. 143.
} 
not substances but divine acts on Ibn Hazm (994-1064). ${ }^{73}$ Today, the Spanish scholar of Islam is famous for his book on love, The Ring of the Dove. His fundamentalist views on Quran interpretation and Islamic law, however, have not prevailed in Islamic jurisprudence.

Similarly, Iqbal refers to the much-read mystic Rumi (1207-1273) as his spiritual guide most of all because Rumi stresses human freedom and fixes narrow limits for predestination: God has destined that we have two hands, but not what we do with them. Iqbal does not follow Rumi where Rumi sings of the unity of all things, but only where Rumi suits him.

\subsection{India}

Iqbal would probably have rejected any influence from Hinduism, even if he saw the struggle between pantheist fatalism and self-asserting activism engrained in every religion. As a member of the Lahore intelligentsia, he still must have been in touch with the tendencies of Hinduism in the early 20 th century. Before the independence of Pakistan, Lahore was only a bit more than $55 \%$ Islamic, it was a centre for the Sikhs, and the Hindu trading castes were very active in society. Moreover, Lahore was the headquarters of the Arya Samaj, a rationalist Hindu reform movement that was against idol worship, propagated the Veda as its holy scripture, denounced all later religions as stupid and proselytized aggressively. Islam in the Punjab was not only attacked by Christian missionaries but also by those of the Arya Samaj, which could only be tackled with rational arguments.

What is more, the discourses of Bengal Neo-Hinduism had already reached Lahore around 1900. Already before Iqbal, Swami Vivekananda had formulated the idea of the self as an enduring entity to be developed. This Hindu monk had impressed the audience at the Parliament of Religions in Chicago in 1893 and given a new self-confidence to the Hindus at home. Based upon this, Sri Aurobindo, another urban middle class Bengali turned guru, coined the catchphrase a $\bar{t}$ mashakti, "the power of the self". This became the slogan of the first non-cooperation movement against Britain, the Swadeshi movement of 1905.

Iqbal does not mention any of this, but he must have noticed it. It may have connected with the philosophy of Fichte in him, which he had to study in order to understand Hegel.

\subsection{Europe}

Iqbal relies on Western science and philosophy much more than on traditional Islamic theology. When quoting the Quran, he does not cite traditional 
commentaries on the Quran, like Țabarī, Ibn al-Kathīr, Jalālain etc., nor modern ones, like al-Alūsī's 19th century commentary Rüḥ al-ma'ānī, and Sir Sayyid Ahmad Khan's modernist commentary neither. Instead, he usually discusses Western science and philosophy, and compares and corrects them with his own perception of the verses. ${ }^{74}$ Discussing the problem of space and time, he begins with Zeno's arrow paradox, dismisses the traditional Asharī view of space consisting of indivisible quanta as incorrect and explains his view using Bertrand Russell, Albert Einstein and Henri Bergson. ${ }^{75}$ We will now examine the influences of the philosophers that shaped his thought, and his interpretation of the Quran.

\subsubsection{Fichte}

For the fact that Iqbal studied him, Hegel himself only plays a small role in Iqbal's thought. ${ }^{76}$ The impact of Hegel's forerunner Fichte must have been much greater, because Fichte's idea that the world outside cannot be known (according to Kant) and we therefore create our world entirely on our own ${ }^{77}$ must have brought him to reconsider his pantheist worldview, perhaps in association with the ätmashaktī theories of the then current Swadeshi movement. In this way, he also arrived at understanding space and time as the construct of one's own thoughts and not out that of God. What is more, Fichte asserts that the self is not a substance but an act, because it does not have any other substance as positing itself. ${ }^{78}$ We see how Iqbal, reading surah 17:85 "The Spirit is by command ( $\min a m r)$ of my Lord" was reminded of the philosophy he had studied and found a justification for the idea that the self is a mere act.

74 Cf. Iqbal 1934, pp. 43-54, where Iqbal cites the Quran to hint at the dynamic, evolving character of the universe, then discusses Bergson's concept of it criticising it for the lack of any purpose, and defines his own position quoting other verses from the Quran, and a verse by the poet 'Urfi (1556-1590).

75 Iqbal 1934, pp. 34-37.

76 Hegel is mentioned only twice in the Reconstruction (p. 68 and 105), and in both cases only shortly as a Western example for a rationalist system of pantheism. In the Message of the East of five years earlier, three poems deal with Hegel. One of them, "Conversation of the deceased" (Iqbāl 1990, p. 368), introduces Hegel's dialectics in two verses. The other two criticise Hegel as too rational for "the way of love" ("Rümì and Hegel", in: Iqbāl 199o, p. 372) and as lacking any consequence ("a hen in mating season that lays eggs without a cock", "Hegel", in: Iqbāl 1990, p. 376).

77 "The self posits itself, and by virtue of this mere self-assertion, it exists." Fichte 1991, p. 97. "In the self I oppose a divisible not-self to the divisible self." Fichte 1991, p. 110. Original: „Das Ich setzt sich selbst ... Ich setze im Ich dem teilbaren Ich ein teilbares Nicht-Ich entgegen." Fichte 1997, p. 16 and 30.

78 "The self ... is at once the agent and the product of action ... action and deed are one and the same, and hence the 'I am' expresses an Act." Fichte 1991, p. 97. 
Without this context, the passage can well be interpreted as "the spirit is of the matters of my Lord", ${ }^{79}$ i.e. none of your business. The passage does not clarify either if it refers to human spirit.

\subsubsection{Kant}

As Dr Reza Hajatpour, now professor of Islamic Religion with a systematic focus at Erlangen University, Germany, once remarked to me, Iqbal may have been the only Islamic philosopher who understood Kant and drew the consequences. Iqbal takes Kant's proofs for the limits of reason for granted, not least in order to counter late 19th century materialism, which rendered reason in terms of absolute and was propagated as high culture. Iqbal criticises Kant in that Kant does not know intuitive knowledge, and bases his own metaphysics on intuition. Like most philosophers, Iqbal is also convinced that no philosopher can avoid Kant. ${ }^{80}$ Lastly, Iqbal was the first to grant access to Kant for thinkers in the Subcontinent, whose education in British traditions did not emphasize the importance of the great German philosopher. ${ }^{81}$

\subsubsection{Goethe}

Goethe has to be mentioned as influential on Iqbal although it was Goethe's Faust that influenced Iqbal's thought. Iqbal has adapted two poems from Goethe and written his Message from the East as an answer to Goethe's WestEastern Divan, ${ }^{82}$ but the figure of Faust has attracted Iqbal's fascination that it contributed to his philosophy. In a poem, Iqbal has his spiritual guide Rumi praise Goethe and attributes Jāmì's famous remark on Rumi "He is not a prophet but he has a book" to Goethe as well. In the next verse, Iqbal clarifies that Goethe's book is "the story of the pact between Satan and the sage", 83 i.e. Faust. Besides a further strengthening of the concept of the self, Iqbal derived from

79 E.g. in the Corpus Coranicum project, see: Corpus Coranicum, surah 17,85 tr. by Nora K. Schmid.

8o Iqbal 1934, pp. 4 et seq.

81 Dar 1965, pp. 29 et seq.

82 Curiously, Iqbal criticized Hafiz for preventing what Goethe loved Hafiz for: enjoying life as it is, including sin, and valuing one's own experience over tradition. However, Iqbal read Hafiz in the tradition of the Indian commentaries as a pantheist mystic, and Goethe read Hafiz according to the Ottoman anti-mystic commentary of Sudi of Bosnia. In early 19th century Europe, Hafiz was needed to impart Ottoman erudition to diplomats, and therefore the German and French reception of Hafiz follows Ottoman tradition.

83 Iqbal: Payām-i Mashriq, in: Iqbal 1990, p. 376. Bahā’uddīn 'Āmulī's remark on Rumi "I do not say that His Excellency / Is a prophet, but he has a book" ("Man namēgōyam ki ān 'Ālïjanāb / Hast paigambar, valì dārad kitāb") means that Rumi may have been a prophet if the last prophet had not come yet. 
Goethe the emphasis on the eternality of the quest for truth. He quotes Goethe in his Lectures to stress that though the development of humankind towards God includes many errors, the ongoing self-revelation of God towards humankind will not fail: "And all the straining, all the striving / Is eternal peace in God."84 Iqbal's concept of heaven as a state of mind of more blissful striving is very close to Goethe's: "Nor is Heaven a holiday. Life is one and continuous. Man marches always onward to receive ever fresh illuminations from an Infinite Reality." ${ }^{15} \mathrm{~A}$ paradise that does not pose a challenge is not what Iqbal calls heaven: Do not live in a world of blind delight / That has God and does not have a devil! ${ }^{86}$ Here, we encounter the ideal of Faust, but as the context shows, adapted to Iqbal's on ideal of developing towards a personality with divine attributes.

\subsubsection{Nietzsche}

Iqbal has adopted not so much Nietzsche's answers as Nietzsche's questions and his critique of Western culture. Iqbal dealt with it intensively from the perspective of a pious Sufi Muslim in the time of his crisis from 1908 to 1915, when he apparently could relate to Nietzsche very well. Nietzsche criticized the rationality of Greek philosophy, which he claimed to have destroyed the celebration of life in "Dionysian" tragedy ${ }^{87}$ Here, we find the source of Iqbal's criticism of Platonism, which he opposed to the "essentially anti-classical" Islam of Arabia. ${ }^{88}$ Pre-Islamic Arabic poetry, i.e. the culture into which the revelation of Islam fell, was a similar joyful acceptance of life in all aspects, and Iqbal lectured Arabic in Lahore University. What is more, according to Nietzsche, philosophy with its assumption that the world is logical has developed into modern science, ${ }^{89}$ the means that the British ruled India with. Thus, Iqbal found the way out of the minority complexes that colonialism had constructed, in a close lecture of the Quran, but under the parameters of individuality and joy of life instead of reason. Together with most philosophers of his time, he regarded Nietzsche as the most important critic of 19th century European civilization, and lets him say in a poem: "This is the tavern 'Europe,' and by the effect of its wine, / What they consider depraved, shows the Praised

\footnotetext{
$84 \quad$ Iqbal 1934, p. 57.

85 Iqbal 1934, p. 117. Cf. above, note 31.

86 "Mazī andar jahān-i kūr-žauqēe / Ki Yazdān dārad-u šaițān nadārad!" Verse 7. Poem "Bihisht" ("Paradise"), in Iqbal: Payām-i Mashriq, in; Iqbal 1990, pp. 301 et seq.

87 Nietzsche: Die Geburt der Tragödie aus dem Geiste der Musik, Fritsch, 1878, chapter 24.

88 Iqbal 1934, p. 4.

89 Nietzsche: Menschliches, Allzumenschliches, Fritsch, 1878, chapter I,11.
} 
One (mahmūd, i.e. Muhammad)." ${ }^{90}$ Iqbal's chapter nine in his Secrets of the Self almost reads like a rhymed paraphrase of the first chapter of Thus spoke Zarathustra, "The Three Metamorphoses". In Nietzsche's book, the spirit must become a camel first, which hastens into wilderness loaded with the quest for truth and the incomprehension of society. In the wilderness, the spirit becomes a lion by getting rid of all conventions and commandments, rejecting all "Thou shalt" and accepting only its own will. Finishing its fight against outer conventions, the lion accepts its will and its world and becomes an innocent child that enjoys life as it is. ${ }^{91}$ Likewise, Iqbal's Secrets of the Self, chapter nine, advocates overcoming external morals, but within the framework of mystical Islam. Here, the obedient camel stands for the commandments of the sharia, and the lion for trusting God alone in the "self-control" of the Sufi path. This path leads to "Divine vice-regency", to becoming God's substitute on earth, doing God's will and renewing the world. ${ }^{92}$ Later, in the Javidnama, Iqbal calls this ideal the "Man of God" (mard-i haqq). ${ }^{93}$ This expression was coined by the mystic Rumi for an accomplished mystic, and Iqbal re-interprets it in his own sense very characteristically here. In chapter ten of the Secrets, Iqbal - not very astonishingly - gives Ali, the close friend and son-in-law of the Prophet, as an example. ${ }^{94}$ Ali is very generally regarded as the mystically inspired hero par excellence in Islam. In this chapter, Iqbal calls power the fruit of life and goes as far as alleging that good becomes evil if someone who knows God calls it evil. ${ }^{95}$ However, the stage of God's vice-regent always depends on the Islamic three steps of law - piety - knowledge of God, and is not free of morality as with Nietzsche. On the contrary, its task is to realize true, i.e. Islamic, morality. In this sense, Maharaja Kishen Pershad was wrong when he regarded Iqbal as a Nietzschean. Iqbal's Man of God may be inspired by Nietzsche, but he does not have much in common with him. Iqbal's Man of God is rather a saint who combines action and contemplation. Iqbal regarded Nietzsche's atheism as an effect of the rationalist culture of Europe and suggested that if Nietzsche had grown up in India, he would have found a good Sufi master and become a saint:

\footnotetext{
90 "İn kharabāt-i Farang ast, va zi ta'șìr-i mai-ash / Ānchi mazmūm shumārand, mēnumāyad Mahmūd." Iqbal: Payām-i Mashriq, in; Iqbal 1990, p. 213.

$91 \quad$ Nietzsche 1961, chapter 1.

92 "Showing that the education of the self has three stages: Obedience, Self-control, and Divine Vicegerence", translation by Reynold Nicholson (see Appendix, translations), Original in: Iqbal 1990 pp. 40-46.

93 Iqbal:Javìdnāma, tr. Arberry, pp. 76 et seq., Original in: Iqbal 1990, pp. 664 et seq.

94 "Setting forth the inner meanings of the names of Ali", translation by Reynold Nicholson (see Appendix, translations), Original in: Iqbal 1990, pp. 47-51.

95 Iqbal 1990, pp. 47-51, verse 1069-1076.
} 
"He stayed in 'No god' and did not reach 'But God' / He stayed an alien to the state of 'His Servant' (= Muhammad)". ${ }^{96}$ The German doctors, however, thought his ecstasy was madness, and destroyed him. ${ }^{97}$

On the other hand, Iqbal and Nietzsche do have in common that they want to replace externally imposed morals by self-determined ethics. Moreover, as we saw, Nietzsche's critique of reason has provided Iqbal with a starting point from which he could tackle 'rational' colonialist governance, and together with Goethe's Faust, Nietzsche's Zarathustra was an impulse to value the joy of life, and the quest for knowledge, over dogmatism. In this way, Iqbal's answers are not those of Nietzsche, but many of Iqbal's questions indeed are. It was questions like whether the Quran supports being a freely thinking individual, whether life on earth is valuable apart from being a preparation for heaven, and what the position of reason is, that Iqbal had in mind reading the Quran. In posing such questions, Iqbal was indeed walking in Nietzsche's footsteps.

\subsubsection{Bergson}

In Henri Bergson, Iqbal finally found a solid theory to hold his rebellious ideas together. Especially Bergson's idea of the élan vital, which spurs evolution, ${ }^{98}$ is of importance here, and intuition as the method of metaphysics. ${ }^{99}$ In his Reconstruction, Iqbal follows Bergson's idea to take a bearing of an issue from two different points of view for the most part. Moreover, he is indebted to Bergson's philosophy of time. ${ }^{100}$ Bergson was immensely popular in his time and was read a lot by Christian theologians as well. He seems to have had this appeal by proving that metaphysics is not irrational, and therefore a rational explanation for religion is possible. For similar reasons, Iqbal can indeed be regarded as a Bergsonist, even if his concept of the self has different roots.

96 Iqbal:Javìdnāma, tr. Arberry, p. 153. Original in: Iqbal 1990, p. 741.

97 Iqbal 1990, p. 741. Iqbal may have heard, or read in Nietzsche, of the German Romantic poet Friedrich Hölderlin (1770-1843), whose poetical career and personality was indeed ruined by psychiatrists in $1805^{-6}$.

98 "Nous revenons ainsi, par un long détour, à l'idée d'où nous étions partis, celle d'un élan originel de la vie, passant d'une génération de germes à la génération suivante de germes par l'intermédiaire des organismes développés qui forment entre les germes le trait d'union. Cet élan, se conservant sur les lignes d'évolution entre lesquelles il se partage, est la cause profonde des variations, du moins de celles qui se transmettent régulièrement, qui s'additionnent, qui créent des espèces nouvelles." Bergson 1913, p. 67.

99 "Nous appelons ici intuition la sympathie par laquelle on se transporte à l'intérieur d'un objet pour coïncider avec ce qu'il a d'unique et par conséquent d'inexprimable. Au contraire, l'analyse est l'opération qui ramène l'objet à des éléments déjà connus, c'estadire communs à cet objet et à d'autres." Bergson 1969, p. 100.

100 Cf. Iqbal's time philosophy in: Iqbal 1934, pp. 51-53. 
Iqbal has gained all his philosophy by meditation of the Quran for years, as he claims, but as an answer to his questions and therefore in the shapes of his thought. His questions, in turn, were shaped by his Islamic and very mystical heritage on the one hand, and by the discourses of early 19th century Lahore and the Western poets and philosophers that he studied on the other hand. If we read his Reconstruction attentively, we find that he tends to criticize classical mainstream Islamic theologians and that he selects Islamic thought, discussing it in order to fit it into the frame of his philosophy. However, he is much less critical of the European scientists and philosophers of his age, whom he discusses at greater length and with little critique. Iqbal's understanding of the Quran, and hence his philosophy, is therefore structured by contemporary Western thought, especially by Kant for the basics, Fichte (and possibly Swami Vivekananda) for developing the concept of the self, Goethe and Nietzsche for a philosophy of life as a value in itself, and later Bergson for methodical intuition. It is nevertheless interesting that he can understand the Quran in this way, and give valid, though not traditional, explanations from his interpretation of the Quran to the problems of the 2oth century. The influence of Western thought on Iqbal is therefore less with regards to content than on the structure of his thought. As the weight of tradition and the dominance of Western culture are still issues in the Islamic world, Iqbal has not lost anything of his actuality today. Rather, his ideas about law, and the question when a Muslim's self-development collides with being a Muslim, are issues still to be elaborated. Iqbal's ideas that God and humankind are "witnesses"101 (if not partners) of each other, and that revelation is indeed God's eternal self-revelation ${ }^{102}$ will give Islamic thinkers quite a nut to crack. For us, he may provide an approach to modern Islamic thought through philosophers we know well, and thus an excellent topic of dialogue with Islam.

\footnotetext{
101 Schimmel 1963, p. 121.

102 Iqbal 1934, p. 57. This is otherwise a typically Christian view of revelation. It has been used as an argument for Trinity by Karl Barth in his Church Dogmatics, section I 2: A God revealing himself fully will be both a revealing God and a revealed God, and because the act of revealing is complete and divine, the act of revelation itself is fully divine, i.e. God, too. This trinity trap can only be avoided if we hold that God does not reveal himself (but a book), or not fully.
} 


\section{Appendix: Translations of Iqbal's Works}

Iqbal is the national poet of Pakistan, and his works are widely available in many languages. Interested researchers may enjoy reading him in their mother tongue. To my knowledge, translations of Iqbal's works currently exist in Arabic, Bosnian, Chinese, Czech, English, French, German, Indonesian, Italian, Japanese, Russian, Spanish, and Turkish. Unfortunately, Dutch and Scandinavian translations are still lacking. Here is a list of translations, in order of the number of translated works.

\section{a) English Translations of Iqbal's Persian and Urdu Works}

- Secrets of the Self (Asrar-i khudi) - A philosophical poem by Sheikh Muhammad Iqbal [1915], tr. by Reynold A. Nicholson, London Macmillan \& Co 1920; new ed. together with The Mysteries of Selflessness [1917], Lahore: Iqbal Academy Pakistan 2014, URL: http://www.iqbal.com.pk/poeticalworks/english-translations/the-secrets-of-the-self (02.09.2019).

- A Message from The East [1923], selected and tr. by Muhammad Hadi Hussain; Lahore: Iqbal Academy Pakistan 1971, rep. 2014.

- Call of the Marching Bell [1924], tr. by M.A.K. Khalil, self-published, St. John's Newfoundland 1997.

- Persian Psalms, part I and II [1927; the lyrical parts], tr. by Arthur Arberry, Lahore: Muhammad Ashraf 1961.

- [Persian Psalms, part III and IV:] The new rose garden of mystery, and the book of slaves, tr. by Muhammad Hadi Husain, Lahore: Muhammad Ashraf 1969 .

- Javid-nama [1932], tr. by Arthur Arberry, London: Routledge 2011.

- Gabriel's Wing [1935], tr. by Syed Akbar Ali Shah, Naeem Siddiqui et al., Islamabad: Modern Book Depot 1979.

- What should then be done, O peoples of the East? [1936] Tr. by Bashir Ahmad Dar, Lahore: Iqbal Academy Pakistan 1977.

- The Rod of Moses [1936], tr. by Syed Akbar Ali Shah, Lahore: Iqbal Academy Pakistan 1983 .

- Armaghan-i Hijaz (The Souvenir from Mecca, postumous 1938), tr. by Q.A. Kabir, Lahore: Iqbal Academy Pakistan 1983.

\section{b) Arabic}

- Dīwān risālat aš-Šarq = Bayām Mašriq ديوان رسالة الشرق = بيام مشرق (The Message of the East), tr. by 'Abd al-Wahhāb 'Azzām, Cairo: Sharikat Nawābig al-Fikr [2010?]. 
- Tajdìd at-tafkìr ad-dīnífil-Islāmpar The Reconstruction of Religious Thought in Islam), Damascus: Markaz al-Nāqid at-Taqāfĩ 2008.

- Dīwān Muhammad Iqbāll: [al-ámāl al-kāmila] [يوان محمد إقبال: [الأعمال الكاملة] (complete edition), ed. 'Abd al-Mājid Gūūī, Damascus / Beirut: Dār Ibn Katīir 2003 .

- Hadīyat al-Hijāz هدية الحجاز (The Souvenir from the Hijaz), tr. by Samīr 'Abd al-Ḥamīd Ibrāhīm and Anīs Manșūr, Cairo: al-Majlis al-A'lá lit-Ṭaqāfa 2002.

- Tatawwur al-fikr al-falsafí fī İān : ishām fì tārīkh al-falsafah al-Islāmīyah تطور الفكر الفلسفي في ايران: اسهام في تاريخ الفلسفة الاسلامية (The Development of Philosophical Thought in Iran), Cairo: ad-Dār al-Fannīyah lin-Našr watTawzī‘ 1989.

- Dīwān janāh Jibrīl ديوان جناح جبريل (Gabriel's Wing), tr. by 'Abd al-Mu'īn Mallūḥī, Damascus: Dār Ṭallās 1989.

- Dìwān, Wal-āna - mādāa naṣbau? Yã umam aš-šarq ديوان، والآن - ماذا نصبع يا امح الشرق (What to do now, O Peoples of the East?), tr. by Mahmood Ahmad Ghazi and Ṣāwī Shatān, Damascus: Dār al-Fikr 1988.

- Risālat al-khulūd aw, Jāwīdnāmah رسالة خاود او جويدنامه tr. by Muḥammad as-Sacî̀d Jamāladdīn, [Cairo]: Mu'assasat Sijill al-'Arab 1974.

- Dīwānal-asrārwal-rumūz ديوان الأسرار والرموز:أسرار إثبات الذات ورموزني الذات ('Secrets of the Self' and 'Mysteries of Selflessness'), tr. by 'Abd al-Wahhāb 'Azzām, [Cairo]: Dār al-Ma'ārif [1956].

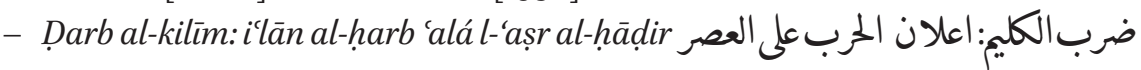
الحاضر (The Rod of Moses), tr. by 'Abd al-Raḥmān 'Azzām, Cairo: Jāmi'at alAzhar lil-Nashr wal-Ta'liff 1952.

c) Turkish

- İslâm felsefesine bir katkı: Iran'da metafizik ilimlerinin tekâmülü (The Development of Metaphysics in Persia), Istanbul: İnsan 1995.

- Benlikve toplum: ('Secrets' and 'Mysteries'), tr. by Ali Yüksel, Istanbul: Eksen Yayınları 1990.

- Şarktan haber (Message from the East), tr. by Ali Nihad Tarlan, Ankara: İş Bankası Kültür Cep Kitapları 1956. 
- Yeni Gülşen-i râz: sir güllerinin açtığı bahçe (The New Rose Garden of Mysteries), tr. by Ali Nihad Tarlan, [Istanbul]: B. Kervan Matbaası [1959].

- Cavidname, tr. by Halil Toker, [Istanbul]: İstanbul Kaknüs Yayınları 2008

- Cebrail'in kanadı (Gabriel's Wing), tr. by Yusuf Salih Karaca, Istanbul: Furkan Yayınları 1977.

- Darb-ı kelim (The Rod of Moses), tr. by Ali Nihad Tarlan, Istanbul: İstanbul Matbaasi 1968.

Moreover, there are several selections of his poems.

\section{d) German}

- Botschaft des Ostens, Ausgewählte Werke, ed. Annemarie Schimmel, Tübingen / Basel: Horst Erdmann 1977.

- Das Buch der Ewigkeit (Javīdnāma, philosophisch-politisches Epos), tr. by Annemarie Schimmel, München: Hueber 1957.

- Steppe im Staubkorn, Texte aus der Urdu-Dichtung Muhammad Iqbals, selected, tr. and ed. by J. Christoph Bürgel, Freiburg / Schweiz: Universitätsverlag 1982.

- Die Wiederbelebung des religiösen Denkens im Islam, tr. by Axel Monte/ Thomas Stemmer: 3rd ed. Berlin 2010.

- Streunende Gedanken, tr. by Axel Monte, München: Ex Oriente 2012.

e) French

- Les Secrets du soi, tr. by Eva de Vitray-Meyerovitch/Albin Michel, coll. "Spiritualités vivantes", Paris 2000.

- Le Livre de l'éternité, tr. by Eva de Vitray-Meyerovitch/Albin Michel, coll. "Spiritualités vivantes", Paris 1962.

- Message de l'Orient, tr. by Eva de Vitray-Meyerovitch/Mohammed Achena, Paris: Les Belles Lettres 1956.

- Reconstruire la pensée de l'Islam, tr. by Eva de Vitray-Meyerovitch, Paris: Adrien Maisonneuve 1955 .

f) Japanese

- Hijäzu no okurimono ヒジャーズの贈物 (The Souvenir from the Hijaz), tr. 片岡弘次 Hiroji Kataoka, Ōsaka: 大同生命国際文化基金 Daidō seimei kokusai bunka kikin, 2018.

- Mūsā no ichigeki ムーサーの一撃 (The Rod of Moses), tr. 片岡弘次 Hiroji Kataoka, Ōsaka: 大同生命国際文化基金 Daidō Seimei Kokusai Bunka Kikin, 2014 . 
- Jiburīru no tsubasa ジブリールの翼 (Gabriel's Wing), tr. 片岡弘次 Hiroji Kataoka, Ōsaka: 大同生命国際文化基金 Daidō Seimei Kokusai Bunka Kikin, 2011.

- Taishō no tabidachi o tsugeru dora no oto : Ikubāru shishū 隊商の旅立ちを 告げる銅鑼の音: イクバール詩集 (The Sound of the Caravan Bell, Collected Poems of Iqbal), tr. 片岡弘次 Hiroji Kataoka, Tōkyō: 花神社 Kashinsha, 2011.

g) Czech

- Rekonstrukce náboženského myšlenív islámu (The Reconstruction of Religious Thought in Islam), tr. by Filip Hajný, Lahore: Iqbal Academy Pakistan 2003.

- Poselstvíz východu: (A Message from the East), tr. by Jan Marek, Prague: Čsav 1960.

- Hlas karavanního zvonku (Call of the Caravan Bell), tr. by Jan Marek, Prague: Odeon 1977 .

\section{h) Indonesian}

- Javid nama = ziarah abadi, tr. by Dewi Candraningrum, Yogyakarta: Fajar Pustaka Baru 2000.

- Membangun kembali pikiran agama dalam Islam (The Reconstruction of Religious Thought in Islam), Jakarta: Tintamas 1966.

- Asrar-i khudi: rahasia pribadi, tr. by Bachrum Rangkuti, Jakarta: Pustaka Islam 1967.

\section{i) Italian ${ }^{103}$}

- Il poema celeste [Javìdnāma], tr. by Alessandro Bausani, Roma: Libreria Editrice ASEQ 2017.

- L'Ala di Gabriele, tr. by Vito Salierno, Lahore: Iqbal Academy Pakistan 2014.

\section{j) Bosnian}

- Razvoj Metafizike U Perziji: Prilog Historiji Muslimanske Filozofije (The Development of metaphysics in Persia), tr. by Nevad Kahteran, Sarajevo: Connectum 2005; Lahore: Iqbal Academy Pakistan 2014.

- Poruka Istoka (A Message from the East), tr. by Džemaludin Latić, Lahore: Iqbal Academy Pakistan 2013; Sarajevo: El-Kalem, s.a.

103 Most of the following translations are taken from the Iqbal Cyber Library of the Iqbal Academy Pakistan. 


\section{k) Chinese}

- Ziwor de mimi 自我的秘密 (The Secrets of the Self), tr. by Liú Shǔxióng 劉曙雄, Beijing: Beijing University Press 北京大學出版社 1999.

- Yīkèbāěr shī xuăn 伊克巴尔诗选 (Selected poems of Iqbal), tr. by Wáng Jiāying 王家瑛, Beijing: People's Literature Publishing House 人民文学出版 社 1977 .

\section{1) Spanish}

- La reconstrucción del pensamiento religioso en el Islam, tr. by Estebán de José Calderón, Lahore: Iqbal Academy Pakistan 1989; Madrid: Trotta 2002.

\section{m) Russian}

- Реконструкиия религиозной мысли в Исламе (The Reconstruction of Religious Thought in Islam), tr. by M T Stepanyanc, Moscow: Vostočnaya literatura RAN 2002.

The collected works of Iqbal, together with English translations, are being put online on the website of the International Iqbal Society, www.iqbal.com. pk. They have been online on the site of the Iqbal Academy Pakistan, www. allamaiqbal.com, which, however, is undergoing a reconstruction. We hope that Iqbal's poetry reappears there soon. Most Urdu and Persian works are also online on http://iqbal.wiki/index.php/Allama_Muhammad_Iqbal, and recited and sung on YouTube.

\section{Biography}

Dr Stephan Popp graduated from Iranian Studies at Bamberg University, Germany. In his thesis, he dealt with the discourses and rhetoric in the Persian poems of the philosopher and posthumous Pakistani national poet Muhammad Iqbal.

His first post-doc project was on the Bahmani sultanate of South India (1347-1509) at Bamberg University, Germany. After, that, he worked at the Viennese Institute of Iranian Studies on the concept of history in the South Indian sultanate of Bijapur (1490-1686). Then he undertook a search for sources on modernizing literature in Iran and Afghanistan. From February 2012 to January 2015, he conducted a research project on "The Chronicles of Shah Jahan" at the Institute of Iranian Studies. In his current project, he examines the development of letter style and essay writing in the Mughal Empire and consequences for Mughal society. 


\section{Bibliography}

Abid, Sayyid Abid Alī: Širr-i Iqbāl ("Iqbal's Poetry”), Lahore 1993.

Aurobindo, Sri (real name Aurobindo Ghose): Integral Yoga: Teaching and Method of Practice, Twin Lakes: Lotus Press 1993.

Aurobindo, Sri (real name Aurobindo Ghose): Der integrale Yoga, Hamburg: Rowohlt 1957.

Bergson, Henri: L'évolution créatrice, Paris: Les Échos de Maquis 1913.

Bergson, Henri: Creative Evolution, New York: Cosimo Classics 2005.

Bergson, Henri: Schöpferische Entwicklung, tr. by Gertrud Kantorowicz, Düsseldorf: Diederichs 1967.

Bergson, Henri: La pensée et le mouvant; Essais et conférences, Articles et conférences datant de 1903 à 1923, 79e édition Paris: Les Presses universitaires de France 1969.

Bose, Sugata/Jalal, Ayesha: Modern South Asia, History, Culture, Political Economy, and ed. London / New York: Routledge 2004.

Bosworth, C.E./van Donzel, E./Heinrichs, W.P./ Pellat, Ch. (eds.): The Encyclopaedia of Islam, New Edition, Leiden / New York: Brill 1993. Cited as usual as: EI².

Corpus Coranicum project, URL: https://corpuscoranicum.de/kommentar/index/ sure/17/vers/1 (date of last access: 02.09.2019).

Catholic Church. Catechism of the Catholic Church: Revised in Accordance with the Official Latin Text Promulgated by Pope John Paul II. Vatican City: Libreria Editrice Vaticana 1997, URL: http://www.vatican.va/archive/ENGoo15/_INDEX. HTM (date of last access: 02.09.2019).

Dar, Bashir Aḥmad: Iqbal and post-Kantian Voluntarism, Lahore 1965.

Dar, Bashir Ahmad: Articles on Iqbal, Lahore: Iqbal Academy Pakistan 1997.

Fichte, Johann Gottlieb: Grundlage der gesamten Wissenschaftslehre, Hamburg: Meiner 1997.

Fichte, Johann Gottlieb: Versuch einer neuen Darstellung der Wissenschaftslehre (1797/98), ed. Peter Baumanns, Hamburg: Meiner 2nd ed. 1984.

Fichte, Johann Gottlieb: The Science of Knowledge, ed. and tr. by Peter Heath and John Lachs, Cambridge: Cambridge Univ. Press 1982, 4th ed. 1991.

Hasan, Mushirul: "Legacy of a Divided Nation, India's Muslims since Independence", in: Barbara Daly Metcalf/Rafiuddin Ahmad/Mushirul Hasan: India's Muslims, An onmibus, Delhi: Oxford University Press 2007.

Hassan, Riffat: The Sword and the Sceptre; A Collection of writings on Iqbal, dealing mainly with his life and poetical works, Lahore: Iqbal Academy Pakistan 1977.

Ibn 'Arabī, Muhyiddīn: Fuṣūṣ al-ḥikam, and the addenda by Abū l-Ilā 'Afîfi, Beirut: Dār al-Kitāb al-'Arabī [1966].

Ibn 'Arabī, Muhyiddīn: Ibn al-'Arabi's Fuṣūṣ al-ḥikam: an annotated translation of "The bezels of wisdom”, tr. by Binyamin Abrahamov, London / New York: Routledge 2015. 
Ibn 'Arabī, Muhyiddīn: Le Livre des chatons des sagesses (Kitâb Fusûs al-hikam), tr. by Charles-André Gilis, Paris: Éditeur AL-Bouraq 1999.

Ibn 'Arabī, Muhyiddīn: Die Weisheit der Propheten [Fuṣūṣ al-ḥikam], tr. from Arabic into

French by Titus Burckhardt; tr. from French into German by Wolfgang Herrmann; introduction by Bulent Rauf, Zürich: Chalice 2005 .

Ibn 'Arabī, Muhyiddīn: al-Futūḥāt al-Makkīyah, ed. 'Abd al-'Azīz Sulțān Ṭāhir Manșūb, Cairo: al-Majlis al-A'lá lit-Taqāfa 2017.

Iqbal, Muhammad: Kulliyāt-i Iqbāl - Fārsī (Collected Persian works of Iqbal), 6th ed. Lahore: Iqbal Academy 1990.

Iqbal, Muhammad: Kulliyāt-i Iqbāl - Urdū (Collected Urdu works of Iqbal), 4th ed. Lahore: Iqbal Academy 1998.

Iqbal, Muhammad: The Reconstruction of Religious Thought in Islam, Oxford etc.: Oxford University Press 1934.

Iqbal, Muhammad: Stray Reflections, The Private Notebook of Muhammad Iqbal, also includes 'Stray Thoughts', ed. with afterword by Dr Javid Iqbal [his son], Lahore: Iqbal Academy Pakistan 3rd ed. 2006.

Iqbal, Muhammad: Letters of Iqbal [in English], compiled and edited by Bashir Ahmad Dar, 2nd ed. Lahore: Iqbal Academy 2005.

Iqbal, Muhammad Kulliyāt-i makātīb-i Iqbāl (Collected letters of Iqbal [in Urdu]), ed. Sayyid Muzaffar Husain Barnī, Delhi: Urdu Academy 1991.

Iqbal Cyber Library of the Iqbal Academy Pakistan, URL: http://iqbalcyberlibrary.net/ en/listsubject/subjectwoi.php (date of last access: 02.09.2019).

Ma'ruf, Muhammad: Iqbal and his Contemporary Western Religious Thought, Lahore: Iqbal Academy Pakistan 1987.

Malik, Ghulam Rasool: Iqbal and the English romantics, New Delhi: Atlantic Publishers 1988.

Metcalf, Barbara Daly: "Islamic revival in British India, Deoband, 1860-1900", in: Barbara Daly Metcalf/Rafiuddin Ahmad/Mushirul Hasan: India's Muslims, An onmibus, Delhi: Oxford University Press 2007.

Munavvar, Muhammad: Iqbal and Quranic Wisdom, Lahore: Islamic Book Foundation 3rd ed. 1992.

Munavvar, Muhammad: Iqbal on human perfection, Lahore: Iqbal Academy Pakistan 2001.

Nietzsche, Friedrich: Human, all Too Human, tr. by R.J. Hollingdale, Cambridge: Cambridge University Press 1997.

Nietzsche, Friedrich: Thus Spoke Zarathustra, tr. by R.J. Hollingdale, London: Penguin 1961.

Nietzsche, Friedrich: Die Geburt der Tragödie aus dem Geiste der Musik, Leipzig: Fritzsch 1878, online: Nietzsche Source, Digitale Kritische Gesamtausgabe von Nietzsches 
Werken und Briefen (eKGWB), URL: http://www.nietzschesource.org/\#eKGWB/ GT-24 (date of last access: 20.08.2019).

Nietzsche, Friedrich: Menschliches, Allzumenschliches, Leipzig: Fritsch 1878, online: Nietzsche Source, Digitale Kritische Gesamtausgabe von Nietzsches Werken und Briefen (eKGWB), uRL: http://www.nietzschesource.org/\#eKGWB/MA-11 (date of last access: 20.08.2019).

Nietzsche, Friedrich: Gesammelte Werke 1859-1888, München: Musarion 1927.

Parthasarathi, Prasannan: Why Europe Grew Rich and Asia did not, Global Economic Divergence, 1600-1850, 3rd ed. Cambridge: Cambridge University Press 2011.

Schimmel, Annemarie: Gabriel's Wing, A Study into the Religious Ideas of Muhammad Iqbāl, Leiden: Brill 1963 .

Schimmel, Annemarie: Muhammad Iqbal, prophetischer Dichter und Philosoph, München: Diederichs 1989 .

Schimmel, Annemarie: Muhammad Iqbal. profetische dichter en filosoof, uit het duits vertaald door W.M. Callewaert, Leuven: Peeters 1990.

Sikand, Yoginder: Bastions of the believers, Madrasas and Islamic Education in India, Delhi: Penguin 2005.

Singh, Iqbal: The Ardent Pilgrim, An Introduction to the Life and Works of Mohammed Iqbal, Delhi: Oxford University Press 2nd ed. 1997.

Smith, Wilfred Cantwell: Modern Islam in India, New York: Russell and Russell 2nd ed. 1972.

Taillieu, Dieter/Laleman, Francis/Callewaert, Winand M: A Descriptive Bibliography of Allama Muhammad Iqbal (1877-1938), Leuven: Peeters 2000.

Vahid, Syed Abdul: Iqbal, His Art and Thought, London: John Murray 1959.

Westminster Shorter Cathechism, URL: https://matt2819.com/wsc/ (date of last access: 02.09.2019). 